\title{
PENGEMBANGAN SISTEM INFORMASI PENGUSULAN, PENILAIAN DAN PENETAPAN ANGKA KREDIT GURU (SIPULPENPAKGURU)
}

\author{
Wawan Kusdiawan \\ STMIK Kharisma Karawang, Teknik Informatika \\ wawankusdiawan8@gmail.com
}

\begin{abstract}
Abstrak
Teacher Performance Assessment is one component in determining the ratings of Credit Master obtained through nomination DUPAK (List of Proposed Establishment of Credit). It is a collection of files that match the rules, bound and delivered to the Secretariat of the assessment team lists the ratings of teacher performance through a number of credits submitted by individual teachers or educators who have become civil servants are useful as one of the requirements at the higher promotion and/or salary or welfare of teachers as functional as well as teacher performance assessment materials or educators such.

The problem faced today is publishing mechanism DUPAK still manual, especially in the process of assessment by the Assessment Team PAK. Thus, in the assessment process in the official report sheet assessment is done in handwritten form in a way, made possible mistakes or errors at the time of entry into application PAK. Teacher understanding of the mechanism of determination of PAK is still low, and the limited number of personnel for data processing. These problem will eventually be detrimental to civil servants, especially teachers concerned.

With the implementation of this applications especially teachers with considerable amounts expected to help because it can improve the accuracy and is able to speed up service. Through the implementation of this SIPULPEKGURU expected nomination process that was previously done manually with the innovations made in this SIPULPENPAKGURU application development, finaly can be made online so that more accurate data, teachers can also monitor the progress of his nomination.
\end{abstract}

Keywords : Guru, Angka kredit, Sistem Informasi, DUPAK. 


\section{PENDAHULUAN}

\section{Latar Belakang}

Penilaian Kinerja Guru merupakan salah satu komponen penilaian dalam penentuan Angka Kredit Guru yang diperoleh melalui pengusulan DUPAK. Daftar Usul Penetapan Angka Kredit (DUPAK) adalah kumpulan berkas yang sesuai dengan peraturan, dijilid dan disampaikan ke Sekretariat tim penilai berisi daftar penilaian kinerja guru melalui angka kredit yang diajukan oleh setiap guru atau tenaga pendidik yang telah menjadi pegawai negeri yang berguna sebagai salah satu persyaratan kenaikan pangkat setingkat lebih tinggi dan/atau gaji atau kesejahteraan guru sebagai jabatan fungsional serta sebagai bahan penilaian kinerja guru atau tenaga pendidik tersebut. Berdasarkan Permenpan Nomor 16 tahun 2009 Angka Kredit adalah satuan nilai dari tiap butir kegiatan dan/atau akumulasi nilai butirbutir kegiatan yang harus dicapai oleh seorang Guru dalam rangka pembinaan karier kepangkatan dan jabatannya.

Kendala yang dihadapi saat ini adalah mekanisme penerbitan DUPAK masih bersifat manual terutama dalam proses penilaian oleh Tim Penilai PAK. Sehingga dalam proses penilaian di lembar berita acara penilaian dilakukan di formulir dengan cara ditulis tangan, dimungkinkan terjadi kesalahan atau kekeliruan pada saat entry ke aplikasi PAK. Pemahaman Guru mengenai mekanisme penetapan PAK masih rendah, serta terbatasnya jumlah personil untuk pengolahan data. Pengajuan, penilaian dan penetapan usul DUPAK guru yang selama ini dilakukan secara manual dan tidak terintegrasi. Proses tersebut menyebabkan terjadi banyak kesalahan data, akurasi, identifikasi, keterlabatan penerbitan PAK yang berdampak pada keterlambatan pengajuan kenaikan pangkat dan kesejahteraan guru. Kesalahan-kesalahan tersebut pada akhirnya akan merugikan PNS terutama guru yang bersangkutan.

Dengan diimplementasikannya aplikasi SIPULPENPAKGURU ini melalui pemanfaatan teknologi informasi bagi proses pengolahan data khususnya PAK guru dengan jumlah yang cukup banyak diharapkan dapat membantu karena dapat meningkatkan akurasi dan mampu mempercepat pelayanan. Melalui implementasi SIPULPEKGURU ini diharapkan proses pengusulan DUPAK yang sebelumnya dilakukan secara manual dengan inovasi yang dilakukan dalam pengembangan aplikasi SIPULPENPAKGURU ini, usul DUPAK guru dapat dilakukan secara online sehingga data lebih akurat, guru juga dapat memantau progress pengusulan DUPAK-nya secara online.

Guru adalah pendidik profesional yang mempunyai tugas, fungsi, dan peran penting dalam mencerdaskan kehidupan bangsa. Profesi guru perlu dikembangkan secara terus menerus dan proporsional menurut jabatan fungsional guru. Selain itu, agar fungsi dan tugas yang melekat pada jabatan fungsional guru dilaksanakan sesuai dengan aturan yang berlaku, maka diperlukan Penilaian Kinerja Guru (PK GURU) yang menjamin terjadinya proses pembelajaran yang berkualitas.

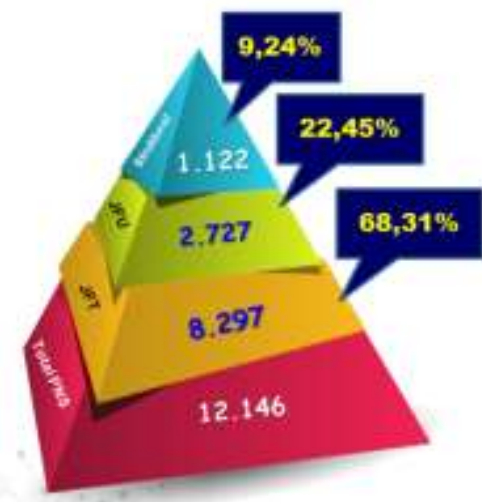

Gambar 1 Grafik Data Pegawai berdasarkan SIMPEG

Lebih dari $60 \%$ pegawai di Kabupaten Karawang adalah tenaga guru. Berdasarkan data SIMPEG per Desember 2016 jumlah pegawai di Kabupaten Karawang sebanyak 12.146 orang terdiri dari Jabatan Struktural sebanyak 1.122 orang, Jabatan Fungsional Umum (JFU) sebanyak 2.727 orang dan Jabatan Fungsional Tertentu (JFT) sebanyak 8.927 orang. Guru merupakan salah satu JFT dengan jumlah terbesar sebanyak 6.506 orang.

Penilaian Kinerja Guru merupakan salah satu komponen penilaian dalam penentuan Angka Kredit Guru yang diperoleh melalui pengusulan DUPAK. Daftar Usul Penetapan Angka Kredit (DUPAK) adalah kumpulan berkas yang sesuai 
dengan peraturan, dijilid dan disampaikan ke Sekretariat tim penilai berisi daftar penilaian kinerja guru melalui angka kredit yang diajukan oleh setiap guru atau tenaga pendidik yang telah menjadi pegawai negeri yang berguna sebagai salah satu persyaratan kenaikan pangkat setingkat lebih tinggi dan/atau gaji atau kesejahteraan guru sebagai jabatan fungsional serta sebagai bahan penilaian kinerja guru atau tenaga pendidik tersebut.

Berdasarkan Permenpan Nomor 16 tahun 2009 Angka Kredit adalah satuan nilai dari tiap butir kegiatan dan/atau akumulasi nilai butir-butir kegiatan yang harus dicapai oleh seorang Guru dalam rangka pembinaan karier kepangkatan dan jabatannya.

Beberapa kendala yang dihadapi dalam penanganan Angka Kredit Guru diantaranya adalah :

1. Kesalahan Penjumlahan/Perhitungan dan kesalahan distribusi Angka Kredit ke daftar DUPAK. Dikarenakan perhitungan dilakukan secara manual dengan komponen penilaian yang banyak maka dibutuhkan ketelitian yang tinggi apabila tidak dapat berakibat pada kesalahan penjumlahan / perhitungan angka kredit serta kesalahan distribusi Angka Kredit ke daftar DUPAK;

2. Identifikasi history data PAK / Inpassing PAK tidak ada. Hal ini sering dijadikan alasan belum menerima atau hilang padahal PAK terakhir adalah kunci untuk proses inpassing dan penetapan PAK berikutnya;

3. Informasi hasil penilaian PAK / Inpassing PAK terbatas, hanya petugas kepegawaian saja yang bisa mengecek status penilaian PAK atau guru yang datang langsung mengkonfirmasi ke sekretariat tim PAK;

4. Keterlambatan Penerbitan PAK sering terjadi, hal ini diakibatkan keterlambatan penandatanganan PAK guru. Proses penerbitan PAK guru sudah berjalan dengan apliaksi akan tetapi untuk pengesahan atau penandatanganan dari pejabat yang berwenang sering mengalami keterlambatan dikarenakan banyaknya jumlah berkas yang harus ditandatangani oleh Kadisdikpora Kabupaten Karawang;
5. Pemahaman Mekanisme Penilaian Angka Kredit kurang, terkadang guru datang ke Badan Kepegawaian dan Diklat (BKD) atau sekarang bernama Badan Kepegawaian dan Pengembangan Sumberdaya Manusia (BKPSDM) melalui Sekretariat Tim PAK untuk mengecek status usul PAK-nya, padahal hal tersebut dapat dilakukan oleh pihak sekolah atau UPTD. Ada juga guru yang masih belum memahami antara usul PAK dengan usul Kenaikan Pangkat, mereka menganggap ketika sudah mengusulkan PAK otomatis naik pangkat padahal PAK adalah salah satu syarat untuk proses Kenaikan Pangkat;

6. Kesulitan menyusun DUPAK, belum semua guru dapat mengusulkan PAK secara rutin setiap tahun, dengan banyaknya jumlah guru dimungkinkan masih ada guru yang belum menerima secara lengkap tentang informasi dan sosialiasi mekanisme atau prosedur pengusulan PAK. Dikarenakan keterabatasan tim dalam melakukan sosialisasi ke sekolahsekolah;

7. Tidak jelasnya informasi progress pengusulan DUPAK, tidak ada informasi yang jelas tentang status pengusulan PAK guru, belum ada standarisasi waktu penerbitan PAK;

8. terbatasnya jumlah personil pada Sekretariat dan Tim Penilai PAK untuk petugas pengolah data dan terbatasnya waktu Tim Penilai PAK mengingat tugasnya rangkap sebagai Guru.

Mekanisme penilaian PAK masih bersifat manual terutama dalam proses penilaian oleh Tim Penilai PAK. Sehingga dalam proses penilaian di lembar berita acara penilaian dilakukan di formulir dengan cara ditulis tangan, dimungkinkan terjadi kesalahan atau kekeliruan pada saat pemrosesan oleh Sekretariat Tim PAK.

Apabila hal ini tidak segera diatasi maka pelayanan PAK guru menjadi tidak optimal dan berakibat pada terlambatnya penetapan PAK guru serta terlambatnya usul kenaikan pangkat khususnya guru. 


\section{RUANG LINGKUP}

Ruang lingkup penelitian ini adalah:

1. Menganalisis dan membangun Sistem Informasi Pengusulan, Penilaian dan Penetapan Angka Kredit Guru;

2. Merancang dan mengembangkan aplikasi sistem informasi Pengusulan Penilaian dan Penetapan Angka Kredit Guru berbasis web;

3. Terprosesnya usul DUPAK pada tingkat SLTP dalam jangka pendek dan jangka panjang pada tingkat SD.

\section{Tujuan}

Tujuan dari penelitian ini adalah :

1. Tujuan Jangka Pendek :

Terprosesnya usul DUPAK guru melalui SIPULPENPAKGURU, sebagai pilot project hanya 4 (empat) sekolah);

2. Tujuan Jangka Menengah :

Terlaksananya SIPULPENPAKGURU ke seluruh Sekolah Lanjutan Tingkat Pertama (SLTP) di lingkungan Dinas Pendidikan Pemuda dan Olah Raga Kabupaten Karawang sebanyak 72 Sekolah;

3. Tujuan Jangka Panjang (1-2 Tahun) : Implemantasi SIPULPENPAKGURU yang terintegrasi di seluruh Sekolah tingkat, SLTP dan Sekolah Dasar sebanyak 851 di lingkungan Dinas Pendidikan Pemuda dan Olah Raga Kab. Karawang;

\section{Manfaat}

Manfaat penelitian ini berdasarkan segmentasi stakeholder yang berhubungan diantaranya adalah:

\section{Bagi Guru}

Dapat mengetahui progress/status proses pengusulan PAK, dengan memanfaatkan aplikasi DUPAK online sehingga untuk mengetahui apakah sudah diusulkan, sedang diperiksa, sedang disahkan tidak harus datang ke Badan Kepegawawan dan Diklat.

2. Bagi Dinas Pendidikan Pemuda dan Olahraga Kabupaten Karawang
Memudahkan kelancaran tugas dalam pelayanan PAK guru, karena dengan diimpelemntasikannya

SIPULPENPAKGURU ini Dinas Pendidikan Pemuda dan Olahraga Kabupaten Karawang sangat dibantu dipermudah dalam proses penerbitan PAK guru.

3. Bagi Reformasi Birokrasi

a. meningkatkan kualitas pelayanan publik kepada masyarakat, dalam hal ini adalah masyarakat Guru;

b. Sistem, proses dan prosedur kerja yang jelas, efektif, efisien, terukur, efisiensi biaya, waktu memotong jalur birokrasi;

c. Mempermudah dan mempercepat proses pelayanan khususnya dalam proses penerbitan PAK Guru.

4. Bagi Tim PAK

Dapat membantu Tim PAK terutama untuk mengatasi permasalahan keterbatasan waktu yang dimiliki oleh Tim PAK yang merangkap sebagai guru dalam melakukan penilaian usul DUPAK guru karena penilaian dapat dilakukan dari sekolah dengan SIPULPENPAKGURU yang berbasis teknologi informasi.

5. Bagi Sekretariat Tim PAK

Dapat mengatasi permasalahan keterbatasan kekurangan personil untuk pengolahan data. Karena tugas entry data dilimpahkan ke Tenaga Operator/Tata Usaha sekolah, sehingga tim sekretariat hanya melakukan finaliasasi verifikasi data akhir dari tim penilai PAK selanjutnya mencetak penetapan PAK.

\section{METODE PENELITIAN}

Dalam penelitiaan ini, peneliti menggunakan teknik pengumpulan data dengan metode:

1. Wawancara

Pedoman wawancara digunakan untuk mengingatkan interviewer mengenai aspekaspek apa yang harus dibahas, juga menjadi daftar pengecek (check list) apakah aspekaspek relevan tersebut telah dibahas atau ditanyakan. Dengan pedoman demikian interviwer harus memikirkan bagaimana pertanyaan tersebut akan dijabarkan secara kongkrit dalam kalimat Tanya, sekaligus menyesuaikan pertanyaan dengan konteks 
actual saat wawancara berlangsung (Patton dalam poerwandari, 1998)

2. Observasi

Dalam penelitian ini observasi dibutuhkan untuk dapat memehami proses terjadinya wawancara dan hasil wawancara dapat dipahami dalam konteksnya. Observasi yang akan dilakukan adalah observasi terhadap subjek, perilaku subjek selama wawancara, interaksi subjek dengan peneliti dan hal-hal yang dianggap relevan sehingga dapat memberikan data tambahan terhadap hasil wawancara.

\section{TINJAUAN PUSTAKA}

Daftar Usul Penetapan Angka Kredit (DUPAK) adalah kumpulan berkas yang sesuai dengan peraturan, dijilid dan disampaikan ke Sekretariat tim penilai berisi daftar penilaian kinerja guru melalui angka kredit yang diajukan oleh setiap guru atau tenaga pendidik yang telah menjadi pegawai negeri yang berguna sebagai salah satu persyaratan kenaikan pangkat setingkat lebih tinggi dan/atau gaji atau kesejahteraan guru sebagai jabatan fungsional serta sebagai bahan penilaian kinerja guru atau tenaga pendidik tersebut. Sedangkan definisi Angka Kredit berdasarkan Permenpan Nomor 16 tahun 2009 adalah satuan nilai dari tiap butir kegiatan dan/atau akumulasi nilai butir-butir kegiatan yang harus dicapai oleh seorang Guru dalam rangka pembinaan karier kepangkatan dan jabatannya.

Landasan hukum Penilaian Angka Kredit guru adalah :

1. Peraturan Menteri Negara Pendayagunaan Aparatur Negara dan Reformasi Birokrasi Nomor 16 Tahun 2009 tentang Jabatan Fungsional Guru dan Angka Kreditnya;

2. Peraturan Bersama Menteri Pendidikan Nasional dan Kepala Badan Kepegawaian Negara Nomor 03/V/PB/2010 Nomor 14 Tahun 2010 tentang Petunjuk Pelaksanan Jabatan Fungsional Guru dan Angka Kreditnya;

3. Peraturan Manteri Pendidikan Nasional Nomor 35 Tahun 2010 tentang Petunjuk Teknis Pelaksanaan Jabatan Fungsional Guru dan Angka Kreditnya;
4. Peraturan Menteri Pendidikan Nasional Nomor 38 Tahun 2010 tentang Penyesuaian Jabatan Fungsional Guru;

5. Peraturan Menteri Pendidikan dan Kebudayaan Nomor 4 Tahun 2014 tentang Penyesuaian Penetapan Angka Kredit Guru Pegawai Negeri Sipil dan Guru Bukan Pegawai Negeri Sipil;

6. Peraturan Menteri Pendidikan Nasional dan Kepala Badan Kepegawaian Negara Nomor : 03/V/PB/2010 Nomor : 14 Tahun 2010 tentang Petunjuk Pelaksanaan Jabatan Fungsional Guru dan Angka Kreditnya.

Fokus penelitian ini adalah pada proses usul DUPAK karena terbatasnya personil di Badan Kepegawaian dan Diklat Kabupaten Karawang terutama untuk petugas pengolah data, terbatasnya waktu yang dimiliki oleh Tim PAK dikarenakan tupoksi utamanya sebagai guru dan kurangnya pemahanan dari beberapa guru tentang prosedur dan mekanisme DUPAK. Apabila hal ini tidak segera diatasi maka pelayanan PAK guru menjadi tidak optimal dan berakibat pada terlambatnya penetapan PAK guru serta terlambatnya usul kenaikan pangkat khususnya guru.

Alasan lain yang menyebakan pentingnya penangan DUPAK guru karena lebih dari $60 \%$ pegawai di Kabupaten Karawang adalah tenaga guru. Berdasarkan data SIMPEG per Desember 2015 jumlah pegawai di Kabupaten Karawang sebanyak 13.587 orang terdiri dari Jabatan Struktural sebanyak 1.717 orang, Jabatan Fungsional Umum (JFU) sebanyak 2.364 orang dan Jabatan Fungsional Tertentu (JFT) sebanyak 11.870 orang. Guru merupakan salah satu JFT dengan jumlah terbesar sebanyak 9.506 orang.

Guru adalah pendidik profesional yang mempunyai tugas, fungsi, dan peran penting dalam mencerdaskan kehidupan bangsa. Profesi guru perlu dikembangkan secara terus menerus dan proporsional menurut jabatan fungsional guru. Selain itu, agar fungsi dan tugas yang melekat pada jabatan fungsional guru dilaksanakan sesuai dengan aturan yang berlaku, maka diperlukan Penilaian Kinerja Guru (PK GURU) yang menjamin terjadinya proses pembelajaran yang berkualitas. 
Jumlah guru tersebar di beberapa sekolah baik tingkat Sekolah Dasar (SD), Sekolah Lanjutan Tingkat Pertama (SLTP) maupun Sekolah Lanjutan Tingkat Atas (SLTA). Berikut adalah data jumlah sekolah di Kabupaten Karawang:

Tabel 1 Jumlah sekolah di Kabupaten

Karawang Tahun 2015

\begin{tabular}{|c|l|c|}
\hline No & \multicolumn{1}{|c|}{ Tingkat Pendidikan } & $\begin{array}{c}\text { Jumlah } \\
\text { Sekolah }\end{array}$ \\
\hline 1 & Sekolah Dasar (SD) & 851 \\
\hline 2 & $\begin{array}{l}\text { Sekolah Lanjutan Tingkat Pertama } \\
\text { (SLTP) }\end{array}$ & 83 \\
\hline 3 & Sekolah Menengah Atas (SMA) & 23 \\
\hline 4 & $\begin{array}{l}\text { Sekolah Menengah Kejuruan } \\
\text { (SMK) }\end{array}$ & 11 \\
\hline \multirow{2}{*}{} & \multicolumn{2}{|c|}{ Total Sekolah } \\
\cline { 2 - 3 }
\end{tabular}

Untuk memperbaiki permasalahan tersebut dipandang perlu mengembangkan sistem informasi penilaian DUPAK guru melalui Pengembangan Sistem Informasi Pengusulan, Penilaian dan Penetapan Angka Kredit Guru (SIPULPENPAKGURU), sehingga dapat meningkatkan pelayanan penerbitan PAK Guru dapat berjalan dengan tepat, cepat dan akuntabel.

\section{ANALISIS SISTEM BERJALAN}

Kendala yang dihadapi saat ini adalah mekanisme penerbitan DUPAK masih bersifat manual terutama dalam proses penilaian oleh Tim Penilai PAK. Sehingga dalam proses penilaian di lembar berita acara penilaian dilakukan di formulir dengan cara ditulis tangan, dimungkinkan terjadi kesalahan atau kekeliruan pada saat entry ke aplikasi PAK. Pemahaman Guru mengenai mekanisme penetapan PAK masih rendah. Terkadang guru datang ke BKD (Sekretariat Tim PAK) untuk mengecek status usul PAK-nya, padahal hal tersebut dapat dilakukan oleh pihak sekolah atau UPTD. Ada juga guru yang masih belum memahami antara PAK dengan Kenaikan Pangkat, mereka menganggap ketika sudah mengusulkan DUPAK otomatis naik pangkat padahal PAK adalah salah satu syarat untuk proses Kenaikan Pangkat. Serta terbatasnya jumlah personil untuk pengolahan data.
Untuk mengatasi masalah tersebut perlu adanya Sistem Informasi Pengusulan, Penilaian Dan Penetapan Angka Kredit Guru (SIPULPENPAKGURU). Adapun alur sistem pemrosesan usul DUPAK yang direncanakan adalah :

1. Guru mengusulkan berkas usul DUPAK ke tenaga operator/Tata Usaha Sekolah;

2. Selanjutnya Tenaga Operator/Tata Usaha Sekolah melakukan verfikasi dan kelengkapan data apabila dinyatakan lengkap Tenaga Operator/Tata Usaha Sekolah menginput data ke Sistem Informasi DUPAK;

3. Setelah data diinput selanjutnya mencetak data nominatif dan nota usul atau pengantar berkas dan daftar nominatif usul DUPAK di tanda tangani kepala sekolah selanjutnya berkas DUPAK dikirim ke Sekretariat Tim PAK;

4. Sekretariat Tim PAK menyerahkan berkas ke Tim PAK untuk dilakukan verifikasi dan penilaian usul DUPAK secara online, setelah selesai melakukan penilaian mencetak Berita Acara penilaian DUPAK dan menandatangani oleh dua orang Tim penilai PAK;

5. Berita acara penilaian DUPAK yang sudah ditandatangani diserahkan ke Sekretariat Tim PAK untuk di verifikasi ulang dan dicetak penetapan angka kreditnya. Selanjutnya penetapan angka kredit tersebut disampaikan kepada pejabat yang berwenang untuk menandatangi dan setelah disahkan diserahkan kepada guru melalui UPTD atau Sekolah.

Implementasi SIPULPENPAKGURU ini diharapkan pelayanan menjadi lebih cepat, tepat, dan akuntebel. Tujuan jangka pendek penelitian ini adalah sosialisasi dan pelatihan bagi tenaga operator sekolah serta terlaksanakanya SIPULPENPAKGURU (pilot project di 4 Sekolah yaitu SDN Karawang Barat VI, SDN Ciampel 1, SMPN 1 Majalaya dan SMPN 1 Banyusari) termasuk penataan Standar Operasional Prosedur (SOP) yang menyesuaikan dengan sistem informasi dimaksud. Berikut gambaran arsitektur aplikasi SIPULPENPAKGURU agar dapat diakses secara online. 


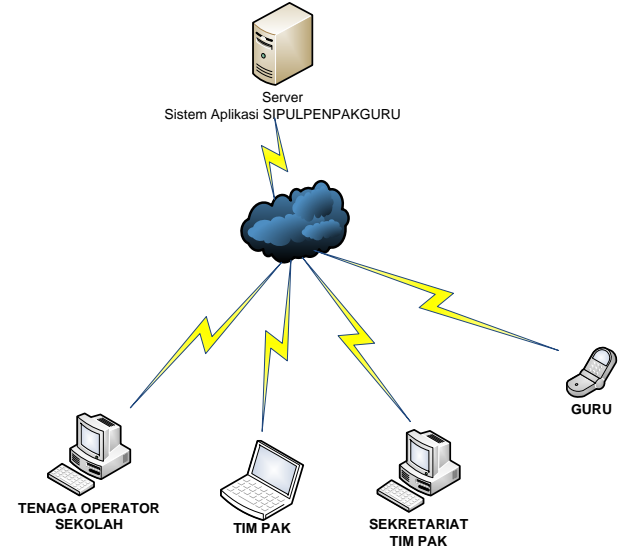

Gambar 2 Arsitektur SIPULPENPAKGURU

Stakeholder yang dipengaruhi atau mempengaruhi terlaksananya penelitian ini sebagai berikut :

a. Stakeholder Internal

1) Kepala Badan Kepegawaian dan Diklat Kabupaten Karawang

2) Kepala Bidang Mutasi Pegawai pada Badan Kepegawaian dan Diklat Kabupaten Karawang

3) Sekretariat Tim PAK

b. Stakeholder External

1) Kepala Dinas Pendidikan Pemuda dan Olahraga Kabupaten Karawang

2) Tenaga operator / Tata Usaha Sekolah

3) Tim Penilai Angka Kredit (PAK)

4) Kepala Sekolah

5) Seluruh Guru di lingkungan Dinas Pendidikan Pemuda dan Olahraga Kabupaten Karawang

6) Kepala Bagian Organisasi Setda Kabupaten Karawang

7) Kementrian Pendidikan dan Kebudayaan Republik Indonesia

8) Kantor Regional III Badan Kepegawaian Negara Bandung

9) Bupati Karawang

\section{PEMBAHASAN}

Untuk mewujudkan kondisi yang diharapkan tersebut perlu adanya Sistem Informasi pengusulan DUPAK Guru melalui SIPULPENPAKGURU sehingga dapat melakukan optimalisasi pelayanan penilaian DUPAK Guru. Rancangan sistem informasi tersebut secara garis besar dapat dilihat pada gambar sebagai berikut :

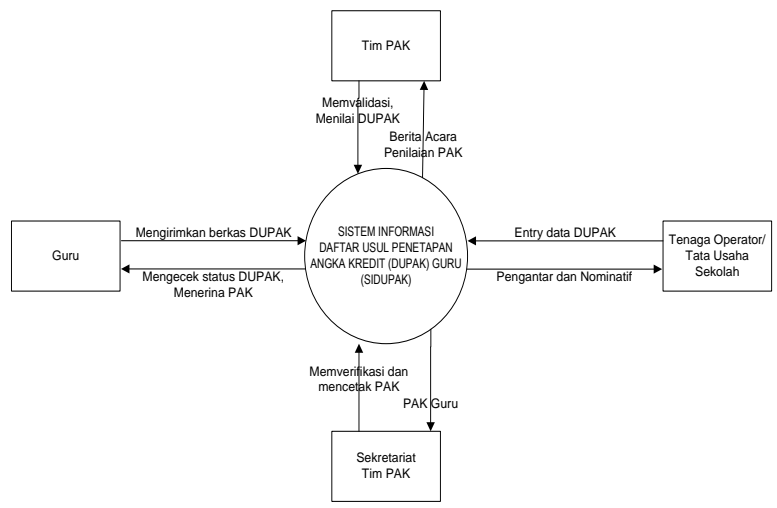

Gambar 3 Alur proses pengusulan DUPAK

Alur proses pengusulan DUPAK yang direncanakan adalah sebagai berikut:

1. Guru mengirimkan berkas usul DUPAK ke sekolah selanjutnya diperiksa dan di-entry ke sistem aplikasi SIPULPENPAKGURU oleh tenaga operator sekolah. Selanjutnya guru dapat mengecek status atau progress usul DUPAK nya melalui media online;

2. Tenaga operator sekolah meng-entry berkas usulan DUPAK ke aplikasi SIPULPENPAKGURU, selanjutnya mencetak nota usul atau daftar nominatif usul DUPAK. Setelah data di entry nota usul atau daftar nominatif usul DUPAK di tanda tangani kepala sekolah selanjutnya berkas DUPAK dikirim ke Sekretariat Tim PAK;

3. Sekretariat Tim PAK menyerahkan berkas ke Tim PAK untuk dilakukan verifikasi dan penilaian usul DUPAK secara online, setelah selesai melakukan penilaian mencetak Berita Acara penilaian DUPAK dan menandatangani oleh dua orang Tim penilai PAK;

4. Berita acara penilaian DUPAK yang sudah ditandatangani diserahkan ke Sekretariat Tim PAK untuk di verifikasi ulang dan dicetak penetapan angka kreditnya. Penetapan angka kredit tersebut disampaikan kepada pejabat yang berwenang untuk menandatangi dan setelah disahkan diserahkan kepada guru melalui UPTD atau Sekolah.

Dengan aplikasi SIPULPENPAKGURU ini dapat mengatasi permasalahan kurangnya waktu 
yang dimiliki oleh Tim Pak karena tugas pokoknya sebagai guru. Serta dengan sistem ini harapannya guru yang sudah mengusulkan PAK dapat memantau progress / status berkasnya secara online, sehingga tidak harus bolak-balik ke sekretariat tim penilai untuk mengecek status usul DUPAK-nya. Serta melalui implementasi aplikasi ini dapat mengatasi permasalahan kekurang personil pada Tim Penilai dan Sekretariat Tim PAK untuk proses pengolahan data.

Output bagi guru adalah dengan mengakses alamat silkbkd.karawangkab.goid guru dapat mengetahui status penilaian PAK.

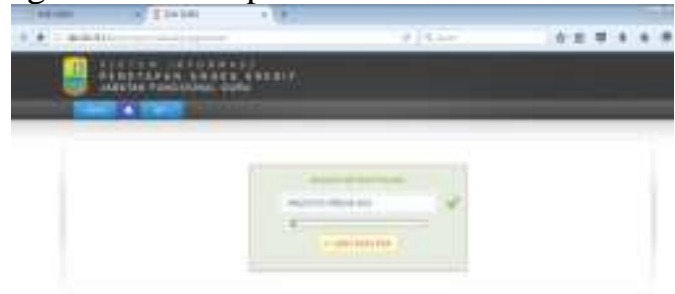

Gambar 4 Guru dapat mengecek usul PAK

Apabila data yang dicari ditemukan maka akan ditampilkan informasi seperti berikut:

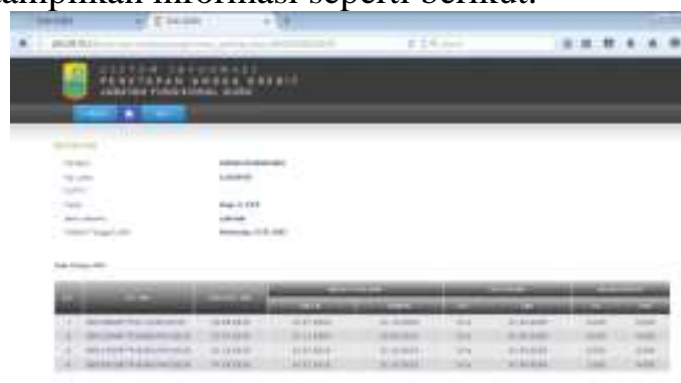

Gambar 5 Informasi Riwayat PAK
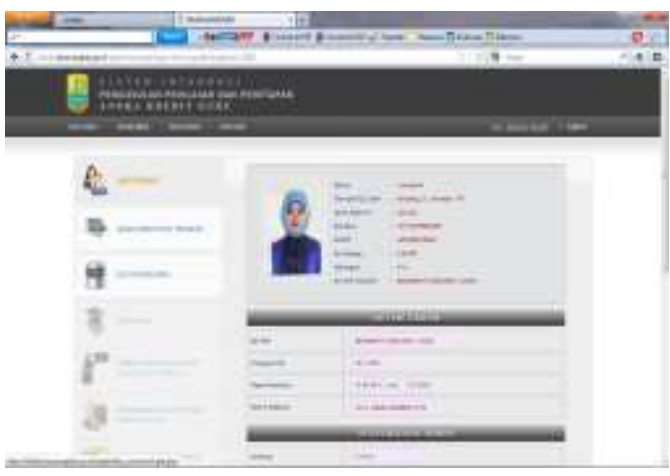

Gambar 6 Informasi PAK dan Profil guru

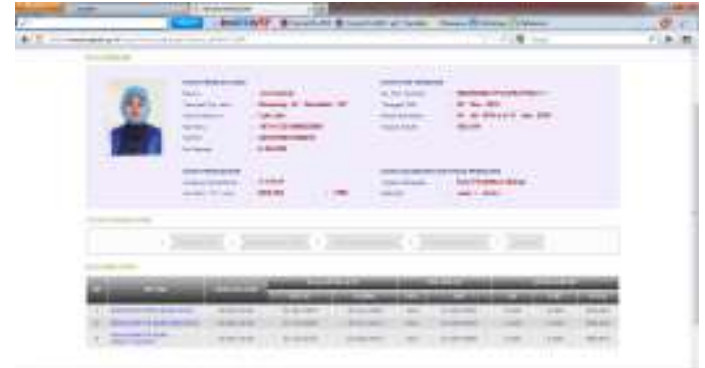

Gambar 7 Status usul DUPAK guru

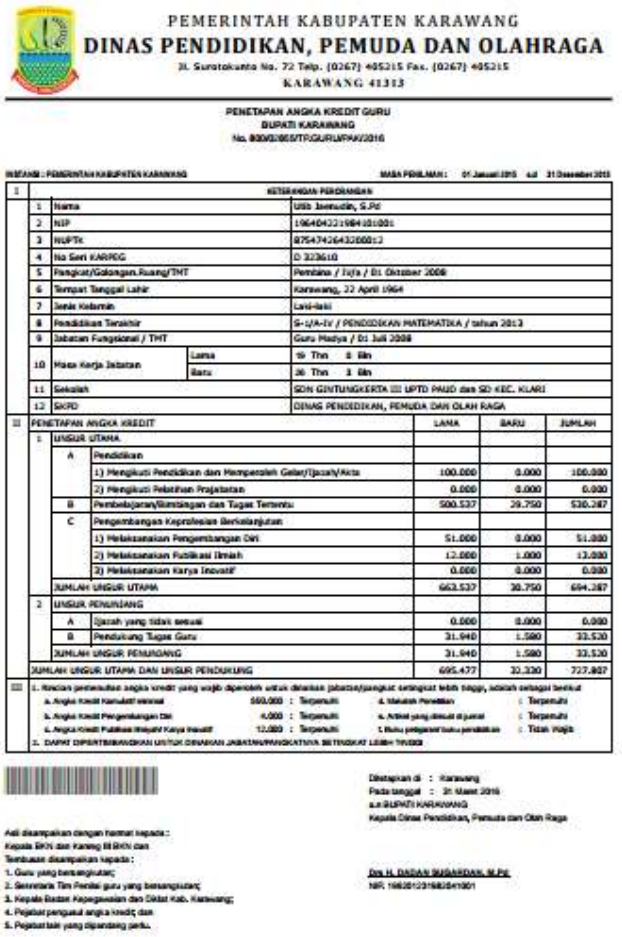

Gambar 8 Output PAK dari aplikasi SIPULPENPAKGURU

Sistem yang diterapkan untuk memantau kemajuan dan mengevaluasi inovasi pelayanan publik ini diantaranya adalah :

1. Visitor counter untuk memantau bera jumlah pengunjung per hari, hari sebelumnya dan total pengunung.

2. Forum komunikasi pengguna, untuk forum tanya jawab menyampaikan masukan dan lain-lain yang sifatnya publik semua user dapat mengakses. 


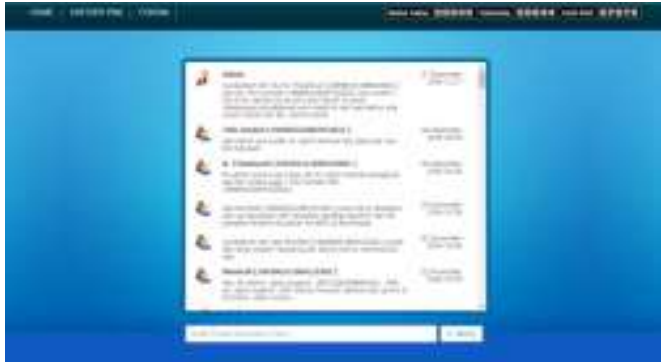

Gambar 9 Forum Komunikasi \& Counter

3. Poolig untuk mengukur tingkat kepuasan pengguna dengan emotion like dan dislike, setiap user yang mengakses aplikasi akan dipandu untuk memberikan poolingnya.

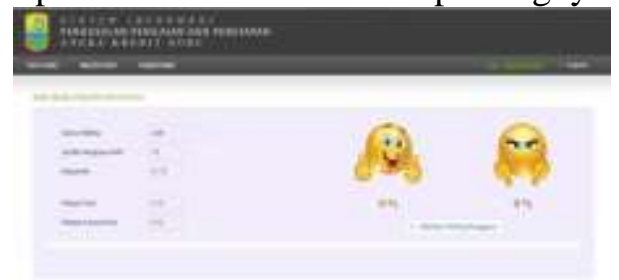

Gambar 10 Pooling Kepuasan pengunjung

4. E-mail untuk mengirim data perbaikan atau memberikan saran dan masukan yang bersifat private;

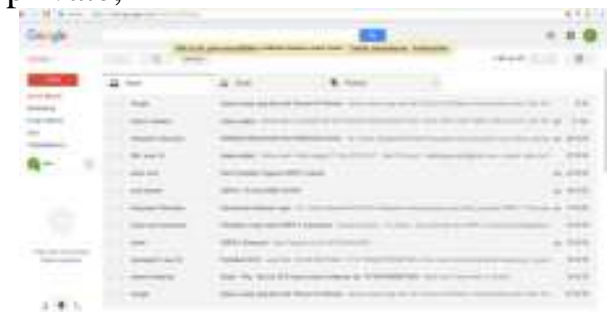

Gambar 11 E-mail komunikasi dan data

5. Forum komunkasi operator sekolah melalui group whatsup, untuk berkomunkasi dan berbagi tentang berbagai hal seputar aplikasi SIPULPENPAKGURU

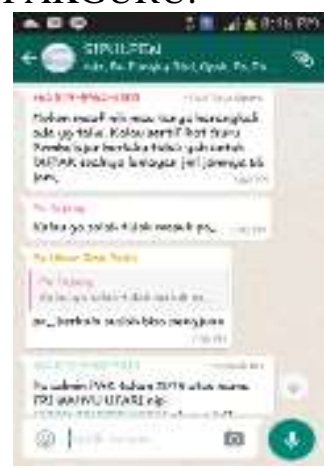

Gambar 12 Forum komunikasi operator di WA
Tabel 2 Perbedaan kondisi sebelum \& sesudah

\begin{tabular}{|c|c|c|}
\hline No & Sebelum & Sesudah \\
\hline 1. & $\begin{array}{l}\text { Kesalahan } \\
\text { Penjumlahan/Perhitungan } \\
\text { usulan PAK oleh Tim PAK } \\
\text { karena dilakukan secara } \\
\text { manual }\end{array}$ & $\begin{array}{l}\text { Penjumlahan / Perhitungan } \\
\text { secara automatis (Tepat / } \\
\text { Akurat) }\end{array}$ \\
\hline 2. & $\begin{array}{l}\text { Identifikasi History Data } \\
\text { PAK / Inpassing PAK tidak } \\
\text { Ada, karena masih } \\
\text { diarsipkan secara manual }\end{array}$ & $\begin{array}{l}\text { Identifikasi History Data } \\
\text { PAK / Inpassing PAK Ada, } \\
\text { karena diarsipkan dalam } \\
\text { database }\end{array}$ \\
\hline 3. & $\begin{array}{lr}\text { Informasi Hasil Penilaian } \\
\text { PAK / Inpassing PAK } \\
\text { Terbatas karena hanya bisa } \\
\text { dikonfirmasi r secara } \\
\text { langsung ke Sekretariat } \\
\text { Tim Penilai Angka Kredit }\end{array}$ & $\begin{array}{l}\text { Informasi Hasil Penilaian } \\
\text { PAK / Inpassing PAK } \\
\text { Terbuka, dapat diakses } \\
\text { melalui web secara online, } \\
\text { dimana saja dan kapan saja } \\
\text { dengan memasukan NIP }\end{array}$ \\
\hline 4. & $\begin{array}{l}\text { Progress Usulan Penilaian } \\
\text { Angka Kredit tidak pasti, } \\
\text { karena belum ada } \\
\text { standarisasi waktu }\end{array}$ & $\begin{array}{l}\text { Kepastian Progress Usulan } \\
\text { Penilaian, dan Penetapan } \\
\text { PAK, karena guru dapat } \\
\text { memonitor status } \\
\text { pengusulan PAK nya }\end{array}$ \\
\hline 5. & $\begin{array}{l}\text { Keterlambatan Penerbitan } \\
\text { PAK sering terjadi, belum } \\
\text { ada SOP }\end{array}$ & $\begin{array}{lr}\text { Keterlampatan } & \text { Penerbitan } \\
\text { PAK perlahan mulai } \\
\text { berkurang, karena sudah } \\
\text { menerapkan sistem dan } \\
\text { tersusunya SOP }\end{array}$ \\
\hline 6. & $\begin{array}{l}\text { Pemahaman Mekanisme } \\
\text { Penilaian Angka Kredit } \\
\text { untuk para guru kurang }\end{array}$ & $\begin{array}{l}\text { Pemahaman Mekanisme } \\
\text { Penilaian Angka Kredit } \\
\text { secara bertahap dipahami } \\
\text { oleh para guru }\end{array}$ \\
\hline 7. & \begin{tabular}{lr}
\multicolumn{2}{l}{ Proses penilaian oleh Tim } \\
PAK dilakukan & secara \\
manual & dengan \\
memanfaatkan & form \\
penilaian &
\end{tabular} & $\begin{array}{l}\text { Proses penilaian oleh Tim } \\
\text { PAK dilakukan secara } \\
\text { online melalui aplikasi, } \\
\text { sehingga mempermudah } \\
\text { dan mempercepat }\end{array}$ \\
\hline 8. & $\begin{array}{lr}\text { Kemanfaatan bagi kalangan } \\
\text { guru dapat meminimalisasi } \\
\text { keterlambatan penerbitan } \\
\text { PAK guru yang } \\
\text { mengakibatkan } \\
\text { keterlambatkan kenaikan } \\
\text { pangkat guru sehingga } \\
\text { berdampak pada nasib guru } \\
\text { dan kesejahteraan serta } \\
\text { profesi guru }\end{array}$ & $\begin{array}{l}\text { Diharapkan } \\
\text { pelayanan DUPAK ini } \\
\text { mampu mengatasi } \\
\text { permasalahan dalam proses } \\
\text { pengusulan, penilaian dan } \\
\text { penetapan PAK guru } \\
\text { karena lebih dari } 60 \% \\
\text { jumlah pegawai di Kab. } \\
\text { Karawang adalah dari } \\
\text { kalangan guru. Dengan } \\
\text { pelayanan yang lebih baik } \\
\text { guru mampu mengajar atau } \\
\text { melayani siswa di sekolah } \\
\text { lebih profesional dan } \\
\text { akhirnya mampu }\end{array}$ \\
\hline
\end{tabular}




\begin{tabular}{|l|l|l|}
\hline & $\begin{array}{l}\text { meingkatkan pelayanan } \\
\text { publik }\end{array}$ \\
\hline
\end{tabular}

\section{KESIMPULAN}

Dengan diimplementasikannya sistem PAK ini pembelajaran yang dapat dipetik adalah pemanfaatan teknologi informasi bagi proses pengolahan data khususnya PAK guru dengan jumlah yang cukup banyak sangat membatu karena dapat meningkatkan akurasi dan mampu mempercepat pelayanan. Reomendasi untuk masa depan diharapkan inovasi seperti ini dapat diimpelemntasikan pada proses pelayanan kepegawaian yang lain.

Sebagai bentuk kelanjutan dan pengembangan dari inovasi ini adalah akan dikembangan proses penilaian PAK guru mulai dari proses pengusulan DUPAK guru yang melibatkan tenaga operator sekolah sehingga dapat mempermudah atau mengurangi beban sekoretariat tim pak dalam proses entry data.

1. Dikarenakan perhitungan dilakukan secara manual dengan komponen penilaian yang banyak maka dibutuhkan ketelitian yang tinggi apabila tidak dapat berakibat pada kesalahan penjumlahan / perhitungan angka kredit.

2. kurangnya pemahaman Guru dalam proses pengusulan DUPAK.

3. Keterlambatan penandatanganan PAK guru, proses penerbitan PAK guru sudah berjalan dengan apliaksi akan tetapi untuk pengesahan atau penandatanganan dari pejabat yang berwenang sering mengalami keterlambatan dikarenakan banyaknya jumlah berkas yang harus ditandatangani oleh Kadisdikpora Kabupaten Karawang.

4. Berkas usulan DUPAK yang lama diusulkan kembali, terdapatnya beberapa berkas usulan DUPAK yang sudah diperiksa seperti karya ilmiah yang pada tahun sebelumnya sudah diusulkan ternyata pada tahun-tahun berikutnya diusulkan kembali, padahal semestinya karya ilmiah yang diusulkan adalah karya yang terbaru.

5. Inpassing dan PAK guru yang belum terintegrasi dengan DUPAK, proses inpassing dan PAK guru yang belum terintegrasi dengan DUPAK, dengan diimplementasikannya aplikai PAK guru sudah sangat membantu dan memudahkan dalam proses penetapan PAK. Akan tetapi dikarenakan keterbatasan jumlah personil menyebaban proses entry data mengalami kesulitan dengan banyaknya jumlah guru.

\section{DAFTAR PUSTAKA}

Bin Ladjamudin, Al-Bahra.(2005). Analisis dan Desain Sistem Informasi. Yogyakarta : Graha Ilmu

Jogiyanto H.M. (2005). Analisis dan Desain Sistem Informasi : Pendekatan Terstruktur Teori dan Praktek Aplikasi Bisnis. Yogyakarta : Andi Offset

Kristanto Andri. (2008). Perancangan Sistem Informasi dan Aplikasinya edisi revisi. Yogyakarta : Gava Media

Peraturan Menteri Negara Pendayagunaan Aparatur Negara dan Reformasi Birokrasi Nomor 16 Tahun 2009 tentang Jabatan Fungsional Guru dan Angka Kreditnya;

Peraturan Bersama Menteri Pendidikan Nasional dan Kepala Badan Kepegawaian Negara Nomor 03/V/PB/2010 Nomor 14 Tahun 2010 tentang Petunjuk Pelaksanan Jabatan Fungsional Guru dan Angka Kreditnya;

Peraturan Manteri Pendidikan Nasional Nomor 35 Tahun 2010 tentang Petunjuk Teknis Pelaksanaan Jabatan Fungsional Guru dan Angka Kreditrnya;

Peraturan Menteri Pendidikan Nasional Nomor 38 Tahun 2010 tentang Penyesuaian Jabatan Fungsional Guru;

Peraturan Menteri Pendidikan dan Kebudayaan Nomor 4 Tahun 2014 tentang Penyesuaian Penetapan Angka Kredit Guru Pegawai Negeri Sipil dan Guru Bukan Pegawai Negeri Sipil;

Peraturan Menteri Pendidikan Nasional dan Kepala Badan Kepegawaian Negara Nomor : 03/V/PB/2010 Nomor : 14 Tahun 2010 tentang Petunjuk Pelaksanaan Jabatan Fungsional Guru dan Angka Kreditnya. 